2

\section{Characterization of Post-haustorial Resistance to Sunflower Broomrape}

Alberto Martín-Sanz ${ }^{\mathrm{a}}$, Begoña Pérez-Vich ${ }^{\mathrm{b}}$, Sandra Rueda ${ }^{\mathrm{a}}$, José M. FernándezMartínez $^{\mathrm{b}}$, and Leonardo Velasco ${ }^{\mathrm{b} *}$

5

6

7

8 apioneer Hi-Bred Agro Servicios Spain SL, La Rinconada, Sevilla, Spain.

9 bInstituto de Agricultura Sostenible (IAS-CSIC). Alameda del Obsipo s/n. 14004

20 Córdoba, Spain.

21 Received

22 *Corresponding author (lvelasco@ias.csic.es). 
The development of durable resistance to broomrape (Orobanche cumana Wallr.) in sunflower (Helianthus annuus L.) requires detailed characterization of the genetic and physiological bases of resistance. The objective of the present study was to map accurately the resistance gene, and to characterize the mechanism of resistance to broomrape observed in a sunflower inbred line (PHSC1102). PHSC1102, which was consistently resistant against race $\mathrm{F}$ and race $\mathrm{G}$ populations of broomrape, was crossed with PHSC1201, which was susceptible to races F and G. A mapping population of 150 $\mathrm{F}_{2}$ genotypes was phenotyped by evaluating $\mathrm{F}_{2: 3}$ families for resistance to broomrape races $\mathrm{F}_{\mathrm{GV}}$ and $\mathrm{G}_{\mathrm{TK}}$. The use of single nucleotide polymorphism (SNP) markers mapped the OrsII gene to linkage group 4 (LG4) of the sunflower genome. Mini-rhizotron and histological studies of the resistant line revealed that the attachment of broomrape to host roots was similar in both the resistant and susceptible lines and that the resistance was observed at a late stage, i.e., after tubercle development. Interestingly, the resistance of the PHSC1102 line was associated with the production of phenolic compounds, which were hypothesized to restrict the parasite's growth. This research provides novel and valuable information about the host-parasite interactions between sunflower and broomrape. 
Sunflower broomrape is a holoparasitic (i.e., a plant not capable of photosynthesis and sustaining itself entirely through parasitism) weed that is widely distributed in sunflower production areas of the Old World. The species has been reported to occur in most of the sunflower producing regions of Spain and France, around the Black and Caspian Seas; in China, and, recently, in some parts of Africa (Fernández-Martínez et al., 2015).

The O. cumana-sunflower system generally involves a qualitative gene-for-gene interaction, in which a dominant resistance gene in the host interacts with a dominant avirulence gene in the parasite, which help eliminate the aboveground symptoms of parasitization (Rodríguez-Ojeda et al., 2013). This system differs from other interactions involving parasitic members of the Orobanchaceae, in which resistance is generally governed by horizontal genetic mechanisms (Pérez-Vich et al., 2013).

Resistance mechanisms can operate at the pre-attachment, pre-haustorial, or posthaustorial stage of Orobanche-host plant interactions (Pérez de Luque et al., 2009). At the pre-attachment stage, the most common resistance mechanisms involve low-level secretions of germination stimulants, germination inhibitors, and inhibitors of radicle development (Höniges et al., 2008). Resistant sunflower germplasm that exhibit low-level secretions of germination stimulants (Labrousse et al., 2001) or of 7-hydroxylated simple coumarins have been reported (Serghini et al., 2001). Pre-haustorial mechanisms operate between the initial contact of broomrape with the host root and the establishment of effective vascular connections (Pérez de Luque et al., 2009). Different mechanisms, such as lignification, suberization, protein crosslinking, and callose accumulation, which contribute to the development of physical barriers that impede penetration by parasitic structures, have been reported (Echevarria-Zomeño et al., 2006; Letousey et al., 2007). The production of chemical compounds, such as phenolics, which are toxic to broomrape, has also been described in sunflower (Echevarria-Zomeño et al., 2006). Post-haustorial 
88 89

mechanisms operate after vascular connections between broomrape and its sunflower host have been established and nodules are visible (Pérez de Luque et al., 2009). Necrosis and subsequent death of broomrape nodules at several stages of development have been reported in sunflower line LR1 (Labrousse et al., 2001; Zélicourt et al., 2007; Louarn et al., 2016). Louarn et al. (2016) detected 17 quantitative trait loci (QTL) associated with resistance to broomrape races $\mathrm{F}$ and $\mathrm{G}$ in a segregating recombinant inbred line (RIL) population derived from a cross between sunflower lines HA89 and LR1 (a line derived from an interspecific cross with Helianthus debilis), which indicated that resistance to broomrape was polygenic.

One source of resistance to sunflower broomrape (i.e., System II resistance) was developed by Pioneer Hi-Bred International in 2008. The mechanism underlying this resistance was thought to be post-haustorial because the resistant genotypes exhibited underground broomrape tubercles that did not emerge under field conditions. In a patent application, Hassan et al. (2008) reported that the trait was controlled by a gene named

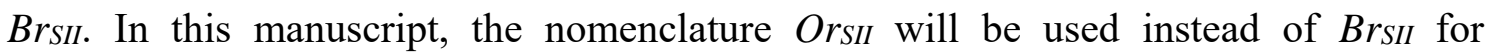
consistency with other broomrape resistance genes. The gene was mapped to linkage group 4 (LG4) of the sunflower genetic map (Hassan et al., 2008). The objective of the present work was to map the OrsII gene with higher resolution, and to characterize the mechanism of resistance.

\section{Plant Materials, Mapping Population, and Phenotypic Evaluation}

Four sunflower germplasms were used in the present study: three F8 inbred lines (PHSC1201, PHSC1102, and PHSC0933), which were developed by Pioneer Hi-Bred, 
and population B117, which was obtained from IAS-CSIC. Line PHSC1201 was resistant to sunflower broomrape races $\mathrm{A}$ to $\mathrm{E}$ (Or5 resistance gene) and susceptible to races $\mathrm{F}$ and G. Line PHSC1102 was the donor of resistance gene OrSII and was developed from the original donors of the resistance described by Hassan et al. (2008). Line PHSC0933 carried the Or7 resistance gene, which provides resistance to races A to G (Duriez et al., 2017). These three inbred lines were produced by Pioneer Hi-Bred using its own germplasm so that it is not possible to establish any relationship with public lines. Meanwhile, B117 was a landrace population of confectionery sunflower collected in Spain (Pérez-Vich et al., 2018), which is susceptible to all sunflower broomrape populations evaluated so far.

Four sunflower broomrape populations were used in the present study: SP, which was collected from the Guadalquivir Valley of Spain and classified as race FGV; GT, which was collected in Turkey and classified as race GTK; IP2, which was collected in Romania and classified as race GRO; and RP4, which was collected in Russia and classified as race GRU. Race nomenclature follows Martín-Sanz et al. (2016). The three race $\mathrm{G}$ populations were chosen because of their high degree of virulence, which was representative of the current predominant level of virulence in Eastern Europe, whereas race $F_{G V}$ was the predominant race in Southern Spain.

A first experiment was designed to evaluate the resistance of line PHSC1102 against a diverse set of sunflower broomrape populations. For that, the three inbred lines and population B117 were evaluated against the four broomrape populations mentioned above. Nine plants for each combination of sunflower line and broomrape population were grown in pots in a greenhouse and evaluated by counting and weighing the emerged and underground broomrape structures (Fig. 1). 

crossed by manual emasculation and pollination. A population of $150 \mathrm{~F}_{2}$ plants from a single $F_{1}$ plant was used for genotyping, and the phenotypic evaluation of broomrape resistance was conducted using $\mathrm{F}_{2: 3}$ families (evaluation of individual $\mathrm{F}_{3}$ plants from each family) against broomrape populations $\mathrm{F}_{\mathrm{GV}}$ and $\mathrm{G}_{\mathrm{TK}}$. The $\mathrm{F}_{2}$ plants were not evaluated for broomrape resistance to maximize $\mathrm{F}_{3}$ seed production through the self-fertilization of individual $\mathrm{F}_{2}$ plants. $\mathrm{F}_{3}$ plants from the $150 \mathrm{~F}_{2: 3}$ families were evaluated for resistance to race $\mathrm{FGV}_{\mathrm{GV}}$ in the field, using two replications of nine plants each, and for race $\mathrm{GTK}_{\mathrm{TK}}$ in pots under open-air conditions, based on 12 plants from each family, in both cases using populations was not feasible because of limited number of $\mathrm{F}_{3}$ seeds available. Broomrape resistance was evaluated by counting emerged broomrape shoots at the end of flowering of sunflower. In the pot evaluation, the height of underdeveloped, emerged broomrape shoots was also measured. Shoot height is easier to measure than shoot weight when evaluating large populations and is similarly associated with System II resistance. No underdeveloped, emerged shoots were observed in the field experiment.

For all experiments, sunflower seeds were germinated on moistened filter paper in small pots $(7 \times 7 \times 7 \mathrm{~cm})$ that contained a 1:1 (by volume) mixture of sand and peat that was carefully mixed with $50 \mathrm{mg}$ broomrape seeds of the corresponding population. The plants were incubated in a growth chamber for $20-25 \mathrm{~d}$ at $25^{\circ} \mathrm{C} / 20^{\circ} \mathrm{C}$ (day/night) under a 16-h photoperiod. For the pot experiments, plants were transplanted to larger pots that contained $5 \mathrm{~L}$ of a 2:1:1 (by volume) soil mixture of sand, silt, and peat and $8 \mathrm{~g}$ controlled-release NPK fertilizer (Nutricote 15-9-10 (2MgO)+ME; Jcam Agri. Co., Ltd, Tokyo, Japan). For the field experiments, FGV-inoculated plants were transplanted to an infested field plot, in which only race-FGV experiments had been conducted since 1999. 
143 A basal application of $500 \mathrm{~kg} \mathrm{ha}^{-1}$ of 8-15-15 NPK fertilizer was made before 144 transplanting. The plants in all experiments were irrigated as required to avoid water 145 stress. The soil, pots, and remaining plants were sterilized in a large capacity (868 L) 146 steam sterilizer (Sterivap 9612-1ED, BMT Medical Technology, Zábrdovice, Czech 147 Republic) after the pot experiments.

Plant Genotyping

The mapping population consisted of $150 \mathrm{~F}_{2}$ plants. Genomic DNA was extracted from lyophilized leaf tissue of each parent and $F_{2}$ plant using a modified cetyl trimethylammonium bromide (CTAB) protocol (Kidwell and Osborn, 1992). The extracted DNA was quantified using an ND 1000 Spectrophotometer (NanoDrop Technologies, Wilmington, DE, USA). The parental lines of the population were genotyped using an Infinium single-nucleotide polymorphism (SNP) array (Illumina, San Diego, CA, USA), which is designed to target polymorphic SNPs (Bachlava et al., 2012). Genome studio ver. 2011.1 (Illumina) was used to make SNP calls, and map positions were assigned according to the consensus genetic map of Bowers et al. (2012). The SNP markers that were polymorphic between the two parental lines were then used to genotype the $\mathrm{F}_{2}$ population using the polymerase chain reaction (PCR)-based KASP (Kompetitive allele specific PCR) genotyping assay (KBioscience, Hoddesdon, UK).

\section{Marker Analysis and Map Construction}

164 All markers were analyzed for the expected segregation ratios of 1:2:1 for codominant 165 markers and 3:1 for dominant markers using the Chi-square test, and only the markers that exhibited Mendelian segregation were used for the analysis. Linkage analysis and genetic distances were calculated using MapDisto 1.7 (Lorieux, 2012), with a minimum 
$\log$ of odds (LOD) score of 4.0 and maximum recombination fraction of 0.2 used to identify linkage groups. The "order sequence" command was used to establish the initial order of markers in each linkage group, and the "ripple order," "check inversions," and "drop locus" commands were used to refine and validate the final order of the markers. The Kosambi function was used to convert recombination fractions to genetic distances. The OrsII gene was mapped by inferring the $\mathrm{F}_{2}$ genotypes from the phenotypes of their $\mathrm{F}_{3}$ progenies. The $\mathrm{F}_{2}$ individuals were classified as $O r_{S I I} O r_{S I I}$ if all their $\mathrm{F}_{3}$ progenies exhibited a resistant phenotype (i.e., System II resistance), OrsII orsII if their F3 progenies segregated for resistance and susceptibility, or orsII orsII if all their $\mathrm{F}_{3}$ progenies exhibited a susceptible phenotype. Linkage was considered significant if the LOD score was $>10.0$. The linkage group map in which the OrsII gene was located was reconstructed in MapDisto using the commands described above, and the map of the linkage group that contained OrsII was drawn using MapChart (Voorrips, 2002).

(1)

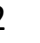

\section{Histological Characterization of Resistance Mechanism}

A modified version of the mini-rhizotron system, described by Pérez de Luque et al. (2005), was used to dissect the phenotypic components of resistance and for histological study. Sunflower seedlings (3 cm radicle length) of the PHSC1201, PHSC1102, and PHSC0933 inbred lines were transferred to square Petri dishes $(15 \times 15 \mathrm{~cm})$ that were filled with vermiculite, with one plant per mini-rhizotron, and then covered with Whatman ${ }^{\circledR}$ glass microfiber filter paper grade GF/A (GE Healthcare Life Sciences, Little Chalfont, UK). After 7-9 d, inoculation was performed by replacing the glass microfiber paper with inoculated glass microfiber paper, on which $O$. cumana seeds $(\sim 10 \mathrm{mg})$ had been homogeneously spread and then conditioned with 2-(N-morpholino) ethanesulfonic acid (MES; $0.3 \mathrm{mM}$ concentration) in darkness at $20{ }^{\circ} \mathrm{C}$ for $10 \mathrm{~d}$. The two broomrape 
populations used to phenotype the mapping population (races $F_{\mathrm{GV}}$ and $\mathrm{G}_{\mathrm{TK}}$ ) were also used in this experiment. After inoculation, the rhizotrons were sealed with parafilm, covered with aluminum foil to exclude light, placed vertically in trays with Universal liquid fertilizer (Compo GmbH, Munster, Germany), and then incubated in a phytotron at $25^{\circ} \mathrm{C} / 22{ }^{\circ} \mathrm{C}$ (day/night) with a 14 -h photoperiod. Infection status was monitored daily using a binocular stereoscopic microscope (Leica M80; Leica Microsystems Wetzlar $\mathrm{GmbH}$, Wetzlar, Germany), and images were captured using a digital camera (Leica IC80 HD, Leica Microsystems). Ten plants per genotype and broomrape race combination were subjected to physiological characterization of resistance and to produce material for histological analysis. After $21 \mathrm{~d}$ of incubation, 200 broomrape seeds that were in close vicinity $(<3 \mathrm{~mm})$ of host roots were studied in each rhizotron using a stereoscopic microscope at 30X magnification. Broomrape germination was assessed as the percentage of seeds with a germ tube, and attachment percentage was determined by counting the broomrape seedlings that were in contact with host roots. The successful penetration of the parasite into the host root tissues was calculated as the percentage of contacted seeds that had initiated penetration. Finally, the number of broomrape tubercles per host plant, their dry weight, and the percentage of necrotic tubercles were recorded. The resulting data were ubjected to an analysis of variance (ANOVA) using InfoStat Software v. 2010. Seedlings and tubercles of O. cumana were sampled with the corresponding attached parts of sunflower roots 7,14 , and $21 \mathrm{~d}$ after inoculation for histological observation.

For staining, the samples were fixed overnight at $4{ }^{\circ} \mathrm{C}$ in $4 \%$ formaldehyde in phosphate-buffered saline (PBS; pH 7.3) solution. After washing in PBS (3 × $15 \mathrm{~min})$, the fixed samples were stored in $0.1 \%$ formaldehyde in PBS at $4{ }^{\circ} \mathrm{C}$. The stored samples were submerged for $24 \mathrm{~h}$ in a solution of $30 \%$ sucrose in PBS, transferred to a beaker with a freezing matrix, and then frozen at $-20{ }^{\circ} \mathrm{C}$ inside a cryostat. Finally, $7 \mu \mathrm{m}$-thick 
sections were cut using a cryostat microtome (Leica CM3050 S; Leica Biosystems

Nussloch GmbH, Nussloch, Germany) and attached to adhesive-treated microscope slides (polysine slides; Menzel GmbH \& Co KG, Braunschweig, Germany).

222 from different mini-rhizotrons, were subjected to histological observation using an

223 Olympus BX61 microscope (Olympus, Hamburg, Germany) that was equipped with an epifluorescence condenser and a Hoechst/DAPI longpass filter set configured at an excitation filter of 340-380 $\mathrm{nm}$. To develop a general overview of the host-parasite interaction, fresh sections were first prepared and photographed. Meanwhile, to detect tannins, lignin, and suberin, other sections were stained using $0.05 \%$ toluidine blue $\mathrm{O}$ (TBO) in PBS (0.1 M, pH 5.5) for 2 min and then rinsed with water for $1 \mathrm{~min}$ (Bordallo et al., 2002). To determine $\mathrm{H}_{2} \mathrm{O}_{2}$ and peroxidase activity, fresh samples were stained with 3,3-diaminobenzidine (DAB) using a modified version of the procedure described by Thordal-Christensen et al. (1997). Briefly, fresh samples were submerged in DAB solution ( $1 \mathrm{mg} / \mathrm{ml}$, in distilled water, $\mathrm{pH} 3.8)$ for $2-3 \mathrm{~h}$, washed using a 1:1:1 mixture of

233 lactic acid, glycerol, and water for $1 \mathrm{~h}$, hand-cut using a razor blade, and then mounted on slides using the 1:1:1 mixture of lactic acid, glycerol, and water. Finally, the accumulation of phenolic compounds in fresh, hand-cut samples was observed using epifluorescence $(340-380 \mathrm{~nm})$. 


\section{Characterization of Resistance in Parental Inbred Lines}

242 The inoculation of PHSC1102 plants with seeds of sunflower broomrape populations $\mathrm{F}_{\mathrm{GV}}$,

$243 \mathrm{G}_{\mathrm{TK}}, \mathrm{G}_{\mathrm{RO}}$, and $\mathrm{G}_{\mathrm{RU}}$ resulted in the absence of or extremely low emergence of broomrape 244 shoots, with a highest mean of 0.5 broomrape shoots per sunflower plant observed for 245 broomrape population $\mathrm{G}_{\mathrm{RU}}$ (Table 1). Meanwhile, the highest mean of emerged broomrape shoots for line PHSC1201 was 9.7, which was observed for broomrape population GRU. Except for population GTK, the number and weight of emerged broomrape shoots on lines PHSC1201 and PHSC1102 were significantly different. In all cases, the emerged broomrape shoots on line PHSC1102 were clearly underdeveloped, characterized by reduced plant growth and the absence of regular flower development (Fig. 1), indicating that the parasite was not able to complete its life cycle on this line. The highest mean broomrape shoot weight on line PHSC1102 was recorded for the emerged GRU broomrape shoots $(67.5 \mathrm{mg})$. This revealed a limited broomrape growth on PHSC1102, as shown by the mean broomrape shoot weight of the GRU population on line PHSC1201 (5799.2 mg) or on the B117 population (5319.0 mg). PHSC1102 plants were also characterized by the presence of underground nodules and shoots. The mean number of underground structures in line PHSC1102 ranged from 4.7 (population GRo) to 56.9 (population $\mathrm{G}_{\mathrm{RU}}$ ), whereas that in line PHSC1201 ranged from 0.1 (population $\mathrm{G}_{\mathrm{TK}}$ ) to 7.4 (population $\mathrm{G}_{\mathrm{RU}}$ ). Differences for the mean number of underground structures in lines PHSC1102 and PHSC1201 were significant for all the broomrape populations (Table 1). It is important to note that the underground nodules and shoots generally lacked necrosis 
became completely necrotic later in sunflower maturity. Line PHSC0933, which carried Or7, was completely resistant to all broomrape populations.

\section{Genetic Mapping}

267

A total of 188 SNP markers that were polymorphic between the two parental lines were used to genotype the $\mathrm{F}_{2}$ population. The SNPs were distributed throughout the species' 17 chromosomes. The OrsII genotypes of the $\mathrm{F}_{2}$ population were deduced by evaluating the $F_{3}$ phenotypes, and the gene was mapped accordingly. The $F_{2}$ genotypes with progenies that were uniformly resistant were assumed to possess the OrsII Orsil genotype, whereas $\mathrm{F}_{2}$ genotypes with progenies that were uniformly susceptible were assumed to possess the orsII orsII genotype, and the $\mathrm{F}_{2}$ genotypes with $\mathrm{F}_{3}$ progenies that segregated for resistance/susceptibility were assumed to possess the OrsII orsII genotype. The OrsII gene was mapped to the upper part of linkage group 4 of the sunflower genome, close (0.7 cM) to SNP marker M-4_30.40 (Fig. 2).

\section{Characterization of Resistance Mechanisms}

279 Table 2 contains a summary of the characterization of resistance performed in minirhizotron experiments to identify the mechanism of resistance acting in PHSC1102. The only statistical difference $(P<0.05)$ detected between lines PHSC1201 and PHSC1102 was the weight of broomrape tubercles, when infected with broomrape races $F_{\text {GV }}$ and $\mathrm{G}_{\mathrm{TK}}$. The broomrape development on the resistant and susceptible lines was clearly different (Fig. 3). The data suggested that the mechanism of OrsII resistance was post-haustorial, acting at the stage of tubercle development. The control line (PHSC0933), which harbored the Or7 resistance gene, exhibited no tubercle development for any of the broomrape races. 

lines of the mapping population that had attached broomrape seedlings. No differences were apparent in either the fresh or TBO-stained specimens, suggesting that the resistance staining, which was performed to detect $\mathrm{H}_{2} \mathrm{O}_{2}$ and peroxidase activity, was inconclusive because strong staining was not observed for any of the genotypes. However, when investigating the accumulation of phenolic compounds using a fluorescence microscope (340-380 nm), intense blue fluorescence was observed inside parasite nodule cells and neighboring host tissue in incompatible interactions, whereas no fluorescence was detected in the compatible interactions of genotype PHSC1201 (Fig. 4). None of the tubercles from line PHSC1201 exhibited fluorescence, whereas $85 \%$ of the nodules from line PHSC1102 exhibited intense fluorescence. This suggested that phenolic compounds were involved in limiting the growth of sunflower broomrape shoots attached to the roots of sunflower line PHSC1102. resistance is generally horizontal, rather than vertical (Pérez-Vich et al., 2013). Complete monogenic dominant resistance in sunflower has been reported against all the broomrape 
races described so far, including races A to E (Vranceanu et al., 1980), race F (PacureanuJoita et al., 2004), and race G (Velasco et al., 2012). Exceptions, in which resistance to sunflower broomrape is controlled by other genetic systems, including control by two independent dominant genes (Pacureanu-Joita et al., 2008), one dominant and one modifying gene (Velasco et al., 2007), one recessive gene (Imerovski et al., 2016), and two recessive genes (Akhtouch et al., 2002), have also been reported, but even in these cases, resistance was characterized by the complete absence of emerged shoots of the parasite. No studies have investigated the mechanisms underlying the resistance mechanisms in resistant donor genotypes, but the absence of broomrape tubercles is an indicator of either pre-attachment or pre-haustorial resistance mechanisms. Incomplete resistance, which is characterized by a reduced number of parasitization structures, has also been reported, although, in those cases, the trait was reported to be quantitatively inherited (Pérez-Vich et al., 2005; Louarn et al., 2016). Accordingly, System II resistance,

which is characterized by the drastic reduction in broomrape growth at the post-haustorial of resistant sunflower genotypes have revealed several mechanisms that occur at different stages of parasitism (Labrousse et al., 2001; Echevarría-Zomeño et al., 2006; Letousey et al., 2007; Zélicourt et al., 2007; Louarn et al., 2016). In those studies, necrosis of broomrape nodules and developing shoots were observed to occur as a result of defensive mechanisms. However, the necrosis of parasite structures observed in the present study occurred very late, after tubercle development. It is likely that this observation was associated with the relatively delayed activation of resistance in line PHSC1102, when compared to other resistance sources. In cases of monogenic control of resistance, e.g., 
the resistance provided by Or5 against broomrape race E, the responsible locus may actually be a cluster of recognition-dependent resistance genes that encode proteins that contain both a nucleotide-binding site (NBS) domain and leucine-rich repeats (LRRs; Lu et al., 2000; Radwan et al., 2008).

In the present study, no physical barriers (e.g., lignin, suberin, or callose) were observed to impede the penetration by broomrape into the host. This suggests that the resistance is the result of another type of defensive mechanism. The intrusive parasite cells easily reached the host cortex and endodermis, and finally the vascular cylinder, which resulted in the development of tubercles and shoots. The data revealed that phenolic compounds were involved in the resistance of sunflower line PHSC1102. Other studies have also reported the association of phenolics with broomrape resistance in sunflower, although at earlier stages. Echevarría-Zomeño et al. (2006), for example, reported that phenolic compounds, together with other resistance mechanisms, such as suberization and protein cross-linking at the cell wall, were involved in the incompatible reaction of race F broomrape and the resistant sunflower line HE-39999. In that study, the authors determined that resistance was achieved by impeding penetration by the parasite. This differs from the mechanism underlying the resistance of line PHSC1102, in which the resistance mechanisms act after vascular connections between the parasite and host have been established. resistance of Medicago truncatula (accession SA4327) against crenate broomrape (Orobanche crenata) and reported mechanisms with some similarity to the mechanisms underlying resistance in line PHSC1102. The authors reported that, even though the parasite attached to SA4327 roots without apparent difficulty, most of the parasitic structures turned necrotic and died before emerging and that phenolic compounds were 
released at the infection point, where host cells made contact with parasite tissues and xylem vessels. In both $M$. truncatula (SA4327) and $H$. annuus (PHSC1102), the accumulation and secretion of phenolic compounds occur at a later stage of infection. This suggests that the host poisons the broomrape structures, thereby inhibiting parasite development, as demonstrated in the present study by differences in the growth of parasites structures in sunflower lines PHSC1102 and PHSC1201. In the present study, fluorescence was observed in the O. cumana tubercle and in the sunflower root tissue that was connected to the tubercle but not in tissues that were located further from the vascular connections. This suggests that the host root produces the phenolic compounds at the infection point. In M. truncatula, the broomrape tubercles that developed on SA4327 became necrotic (Lozano-Baena et al., 2007). However, this was not observed in sunflower line PHSC1102.

Despite remarkable differences in the size and weight of broomrape tubercles attached to PHSC1201 and PHSC1102, no tubercle necrosis was observed in the minirhizotron study. In the pot experiments, necrosis was observed to occur very late, at the time of sunflower maturity (Fig. 1). There are several examples of phenolics providing disease resistance in crops. In some cases, phenolics have been demonstrated to inhibit spore germination of phytopathogenic fungi, whereas, in other cases, phenolic compounds have been demonstrated to inhibit mycelial growth (Lattanzio et al., 2006). The results of the present study suggest that phenolic compounds are involved in the delayed parasite development observed in the PHSC1102-O. cumana system. However, it remains unclear whether the necrosis observed in broomrape plants at the end of the sunflower cycle is a consequence of phenolic compounds or just the result of sunflower maturity. 
Several genes conferring resistance to sunflower broomrape have been mapped in sunflower. Or5, which confers resistance to broomrape race E, has been mapped to a telomeric region of LG3 (Lu et al., 2000; Tang et al., 2003; Pérez-Vich et al., 2004); and Imerovski et al. (2013; 2016) identified SSR markers on LG3 that were strongly associated with resistance genes (Or2, Or3, Or6, and orab-vl-8) that conferred resistance to races B, C, F, and higher than F, respectively. Meanwhile, Duriez et al. (2017) mapped Or7, which confers resistance to race F, to LG7. A number of resistance-related quantitative trait loci (QTL) have also been identified in lines with oligogenic (PérezVich et al., 2004) and polygenic (Louarn et al., 2016) resistance mechanisms. In the present study, a major gene controlling post-haustorial resistance to broomrape was mapped to LG4, confirming the previous results of Hassan et al. (2008). The position of the gene has been more accurately determined in the present research, with markers very close to the gene (Fig. 2). No other broomrape resistance genes have been reported to date in LG4. The defensive genes mapped on that chromosome corresponded to $\mathrm{Pl}_{17}, \mathrm{Pl}_{19}$, $\mathrm{Pl}_{27}, \mathrm{Pl}_{28}$, and $\mathrm{Pl}_{29}$, which are downy mildew resistance genes located in the interval between 2.18-8.51 $\mathrm{Mb}$ in the reference genome of XRQ inbred line (Qi et al., 2015; Zhang et al., 2017; Pecrix et al., 2018), and were located upstream of OrsII. The development of durable broomrape resistance in sunflower will require detailed characterization of the genetic and physiological bases of resistance sources, which are needed to set up gene pyramiding strategies based on physiology-based criteria. 407 Ideally, gene pyramiding should include genes that combine different mechanisms of resistance to establish barriers that cannot be easily overcome by the parasite (Rubiales, 2018). Several studies have been conducted in sunflower, in regards to pyramiding resistance genes for downy mildew (Qui et al., 2015; 2017), but little research has been conducted on gene pyramiding strategies for broomrape resistance. The present study 
412 characterized a novel resistance mechanism for broomrape resistance, which involved the

413 impairment of broomrape growth after the establishment of vascular connections.

414 Because of the presence of a different physiological mechanism relative to other

415

416

417

418

419

420

421

422

423

424

425

426

427

428

429

430

431

432

433

434

435

436

8
resistance sources, the OrsII gene is a good candidate for gene pyramiding strategies, along with other promising genes, such as Or7 and $\operatorname{Or}_{d e b 2}$, both of which provide resistance to race $\mathrm{G}$ populations of sunflower broomrape.

列

We are grateful to Placida Nieto and Alberto Merino, for excellent technical support, and to Dr. Alejandro Pérez de Luque, for valuable advice in the development and interpretation of the histological study.

\section{ACKNOWLEDGMENTS}


Bowers, J.E., E. Bachlava, R.L. Brunick, L.H. Rieseberg, S.J. Knapp, and J.M. Burke. 2012. Development of a 10,000 locus genetic map of the sunflower genome based on multiple crosses. Genes Genomes Genet. 2:721-729.

Duriez, P., S. Vautrin, M. Lopez-Sendon, M.C. Boniface, N. Pouilly, H. Bergès, J. Bazerque, F. Gentoux, C. Paris, J. Piquemal, and S. Muños. 2017. Molecular characterization of the major resistance gene Or7 controlling resistance to $O$. cumana in sunflower. In: Book of Abstracts of the 14th World Congress on Parasitic Plants, Pacific Grove, CA, July 25-30, 2017. International Plant Parasitic Society, p. 22.

Echevarría-Zomeño, S., A. Pérez-de-Luque, J. Jorrín, and A. Maldonado. 2006. Prehaustorial resistance to broomrape (Orobanche cumana) in sunflower (Helianthus annuus): cytochemical studies. J. Exp. Bot. 57:4189-4200.

Fernández-Martínez, J.M., B. Pérez-Vich, and L. Velasco. 2015. Sunflower broomrape (Orobanche cumana Wallr.) In: E. Martínez-Force, N.T. Dunford, and J.J. Salas, editors, Sunflower oilseed. Chemistry, production, processing and utilization. AOCS Press, Champaign, IL, p. 129-156.

Hassan, E.S.A.R.S., E. Hoeft, Z. Li, and L. Tulsieram. 2008. Genetic markers for Orobanche resistance in sunflower. US Patent Publication US/2008/0178325 A1. See: (https://www.lens.org/images/patent/WO/2008083198/A2/WO 2008083198 A $\underline{\text { 2.pdf) }}$

Höniges, A., K. Wegmann, and A. Ardelean. 2008. Orobanche resistance in sunflower. Helia 49:1-12. 
Imerovski, I., A. Dimitrijevic, D. Miladinovic, B. Dedic, S. Jocic, B. Kovacevic, and D. Obreht. 2013. Identification of PCR markers linked to different Or genes in sunflower. Plant Breeding 132:115-120.

Imerovski, I., A. Dimitrijevic, D. Miladinovic, B. Dedic, S. Jocic, N.K. Tubic, and S. Cvejic. 2016. Mapping of a new gene for resistance to broomrape races higher than F. Euphytica 209:281-289.

Kidwell, K.K., and T.C. Osborn. 1992. Simple plant DNA isolation procedures. In: J.S. Beckmann and T.C. Osborn, editors, Plants genomes: methods for genetic and physical mapping, Kluwer Academic Publishers, The Netherlands, p. 1-13.

Lattanzio, V., V.M.T. Lattanzio, and A. Cardinali. 2006. Role of phenolics in the resistance mechanisms of plants against fungal pathogens and insects. In: F. Imperato, editor, Phytochemistry: advances in research. Research Signpost, India, p. 23-67.

Labrousse, P., M.C. Arnaud, H. Serieys, A. Bervillé, and P. Thalouan. 2001. Several mechanisms are involved in resistance of Helianthus to Orobanche cumana Wallr. Ann. Bot. 88:859-868.

Letousey, P., A. De Zélicourt, C. Vieira Dos Santos, S. Thoiron, F. Monteau, P. Simier, P. Thalouarn, and P. Delavault. 2007. Molecular analysis of resistance mechanisms to Orobanche cumana in sunflower. Plant Pathol. 56:536-546.

Lorieux, M. 2012. MapDisto: fast and efficient computation of genetic linkage maps. Mol. Breed. 30:1231-1235.

Louarn, J., M.C. Boniface, N. Pouilly, J. Issakoff, L. Velasco, B. Pérez-Vich, P. Vincourt, and S. Muños. 2016. Sunflower resistance to broomrape is controlled by specific QTLs for different parasitism stages. Front. Plant. Sci. 7:590. 
Lozano-Baena, M.D., E. Prats, M. Teresa Moreno, D. Rubiales, and A. Pérez de Luque. 2007. Medicago truncatula as a model for nonhost resistance in legume-parasitic plant interactions. Plant Physiol. 145:437-449.

Lu, Y.H., J.M. Melero-Vara, J.A. García-Tejada, and P. Blanchard. 2000. Development of SCAR markers linked to the gene Or5 conferring resistance to broomrape (Orobanche cumana Wallr.) in sunflower. Theor. Appl. Genet. 100:625-632.

Martín-Sanz, A., J. Malek, J.M. Fernández-Martínez, B. Pérez-Vich, and L. Velasco. 2016. Increased virulence in sunflower broomrape (Orobanche cumana Wallr.) populations from southern Spain is associated with greater genetic diversity. Front. Plant Sci. 7:589.

Pacureanu-Joita, M., S. Raranciuc, D. Stanciu, E. Sava, and D. Nastase. 2008. Virulence and aggressiveness of sunflower broomrape (Orobanche cumana Wallr.) populations, in Romania. Romanian Agric. Res. 25:47-50.

Pacureanu-Joita, M., C. Veronesi, S. Raranciuc, and D. Stanciu. 2004. Parasite-host plant interaction of Orobanche cumana Wallr. (Orobanche cernua Loefl.) with Helianthus annuus. In: G.J. Seiler, editor, Proc. 16th Int. Sunflower Conf., Fargo, ND, Aug 29-Sept 2, 2004. International Sunflower Association, Paris, France, p. $171-177$.

Pecrix, Y., C. Penouilh-Suzette, S. Muños, F. Vear, and L. Godiard. 2018. Ten broad spectrum resistances to downy mildew physically mapped on the sunflower genome. Front. Plant Sci. 9:1780.

Pérez de Luque, A., S. Fondevilla, B. Pérez-Vich, R. Aly, S. Thoiron, P. Simier, M.A. Castillejo, J.M. Fernández-Martínez, J. Jorrín, D. Rubiales, and P. Delavault. 2009. Understanding Orobanche and Phelipanche host plant interactions and developing resistance. Weed Res. 49:8-22. 
Pérez de Luque, A., D. Rubiales, J.I. Cubero, M.C. Press, and J. Scholes. 2005. Interaction between Orobanche crenata and its host legumes: unsuccessful haustorial penetration and necrosis of the developing parasite. Ann. Bot. 95:935-942.

Pérez-Vich, B., M.R. Aguirre, B. Guta, J.M. Fernández-Martínez, and L. Velasco. 2018. Genetic diversity of a germplasm collection of confectionery sunflower landraces from Spain. Crop Sci. 58:1972-1981.

Pérez-Vich, B., B. Akhtouch, S.J. Knapp, A.J. Leon, L. Velasco, J.M. FernándezMartínez, and S.T. Berry. 2004. Quantitative trait loci for broomrape (Orobanche cumana Wallr.) resistance in sunflower. Theor. Appl. Genet. 109:92-102.

Pérez-Vich, B., L. Velasco, J. Muñoz-Ruz, J. Domínguez, and J.M. Fernández-Martínez. 2005. Registration of three sunflower germplasms with quantitative resistance to race F of broomrape. Crop Sci. 46:1406-1407.

Pérez-Vich, B., L. Velasco, P.J. Rich, and G. Ejeta. 2013. Marker-assisted and physiology-based breeding for resistance to root parasitic Orobanchaceae. In: D.M. Joel, J. Gressel, and L.J. Musselman, editors, Parasitic Orobanchaceae. Parasitic mechanisms and control strategies, Springer, New York, p. 369-391.

Qi, L.L., Y.M. Long, C.C. Jan, G.J. Ma, and T.J. Gulya. 2015. Pl17 is a novel gene independent of known downy mildew resistance genes in the cultivated sunflower (Helianthus annuus L.). Theor. Appl. Genet. 128:757-767.

Qi, L.L., Z.I. Talukder, B.S. Hulke, and M.E. Foley. 2017. Development and dissection of diagnostic SNP markers for the downy mildew resistance genes Pl Arg and Pl 8 and maker-assisted gene pyramiding in sunflower (Helianthus annuus L.). Mol. Genet. Genomics 292:551-563.

Radwan, O., S. Gandhi, A. Heesacker, B. Whitaker, C. Taylor, A. Plocik, R. Kesseli, A. Kozik, R.W. Michelmore, and S.J. Knapp. 2008. Genetic diversity and genomic 

distribution of homologs encoding NBS-LRR disease resistance proteins in sunflower. Mol. Genet. Genomics 280:111-125.

Rodríguez-Ojeda, M.I., R. Pineda-Martos, L.C. Alonso, J. Fernández-Escobar, J.M. Fernández-Martínez, B. Pérez-Vich, and L. Velasco. 2013. A dominant avirulence gene in Orobanche cumana triggers Or5 resistance in sunflower. Weed Res. $53: 322-327$.

Rubiales, D. 2018. Can we breed for durable resistance to broomrapes? Phytopathol. Mediterr. 57:170-185.

Serghini, K., A. Pérez-de-Luque, M. Castejón-Muñoz, L. García-Torres, and J.V. Jorrín. 2001. Sunflower (Helianthus annuus L.) response to broomrape (Orobanche cernua Loefl.) parasitism: induced synthesis and excretion of 7-hydroxilated simple coumarins. J. Exp. Bot. 52:2227-2234.

Tang, S., A. Heesacher, V.K. Kishore, A. Fernández, E.S. Sadik, G. Cole, and S.J. Knapp. 2003. Genetic mapping of the Or5 gene for resistance to Orobanche race E in sunflower. Crop Sci. 43:1021-1028.

Thordal-Christensen, H., Z. Zhang, Y. Wei, and D.B. Collinge. 1997. Subcellular localization of $\mathrm{H}_{2} \mathrm{O}_{2}$ in plants. $\mathrm{H}_{2} \mathrm{O}_{2}$ accumulation in papillae and hypersensitive response during the barley-powdery mildew interaction. Plant J. 11:1187-1194.

Velasco, L., B. Pérez-Vich, C.C. Jan, and J.M. Fernández-Martínez. 2007. Inheritance of resistance to broomrape (Orobanche cumana Wallr.) race F in a sunflower line derived from wild sunflower species. Plant Breeding 126:67-71.

Velasco, L., B. Pérez-Vich, A.A.M. Yassein, C.C. Jan, and J.M. Fernández-Martínez. 2012. Inheritance of resistance to sunflower broomrape (Orobanche cumana Wallr.) in an interspecific cross between Helianthus annuus and Helianthus debilis subsp. tardiflorus. Plant Breeding 121:220-221. 
559 Voorrips, R.E. 2002. MapChart: software for the graphical presentation of linkage maps and QTL. J. Hered. 93:77-78.

561 Vranceanu, A.V., V.A. Tudor, F.M. Stoenescu, and N. Pirvu. 1980. Virulence groups of

562

563

564

565

566

567

568

569

570

571

572
Orobanche cumana Wallr. differential hosts and resistance sources and genes in sunflower. In: Proc. 9th Int. Sunflower Conf., Torremolinos, Spain, July 8-13, 1980. International Sunflower Association, Paris, France, p. 74-80.

Zélicourt, A., P. Letousey, S. Thoiron, C. Campion, P. Simoneau, K. Elmorjani, D. Marion, P. Simier, and P. Delavault. 2007. Ha-DEF1, a sunflower defensin, induces cell death in Orobanche parasitic plants. Planta 226:591-600.

Zhang, Z.W., G.J. Ma, J. Zhao, S.G. Markell, and L.L. Qi. 2017. Discovery and introgression of the wild sunflower-derived novel downy mildew resistance gene Pl19 in confection sunflower (Helianthus annuus L.). Thero. Appl. Genet. 130:2939. 


\section{Figure legends}

574 Figure 1. Phenotypic responses of OrsII-homozygous and -heterozygous sunflower plants

575 to broomrape infection. A, emerged broomrape on homozygous plant; B, subterranean 576 broomrape nodules on homozygous plant; C, emerged broomrape on heterozygous plant;

577 D, subterranean broomrape nodules on heterozygous plant; E, phenotype of susceptible 578 inbred line (PHSC1201); F, necrosis observed in the apex of broomrape tubercles at 105

$579 \mathrm{~d}$ after sunflower sowing. Pictures depict greenhouse-grown sunflower plants that were 580 inoculated with broomrape population GTK at $90 \mathrm{~d}$ after sunflower sowing.

581

582 Figure 2. Genetic map of sunflower linkage group 4 (LG4). LG4 harbors OrsII, which controls post-haustorial resistance to sunflower broomrape in sunflower line PHSC1102.

Figure 3. Phenotypic responses of sunflower lines at $21 \mathrm{~d}$ after broomrape infection. A, PHSC1201; B, PHSC1102; C, PHSC0933. Sunflower plants were inoculated with broomrape population $\mathrm{G}_{\mathrm{TK}}$ in mini-rhizotrons. Small squares on the top left corner show detailed pictures of root-level responses observed with a stereomicroscope at $14 \mathrm{~d}$ after infection.

590

591

Figure 4. Fresh hand-cut sections of sunflower roots and broomrape tubercles collected at $21 \mathrm{~d}$ after inoculation. A, susceptible line (PHSC1201); B, resistant line (PHSC1102). Sections were observed under fluorescence $(340-380 \mathrm{~nm})$, with fluorescence indicating the accumulation of phenolic compounds. hc, host cortex; pha, parasite haustorium; pt, parasite tubercle. 
Table 1. Resistance of sunflower lines PHSC1201 and PHSC1102, control resistant line PHSC0933, and control susceptible population B117 to several populations of sunflower broomrape.

\begin{tabular}{|c|c|c|c|c|c|c|c|c|}
\hline & \multicolumn{2}{|c|}{$\mathrm{F}_{\mathrm{GV}}$} & \multicolumn{2}{|c|}{$\mathrm{G}_{\mathrm{TK}}$} & \multicolumn{2}{|c|}{ GRO } & \multicolumn{2}{|c|}{ GRU } \\
\hline & $\mathrm{N}^{\dagger}$ & $\mathrm{Wt}^{\dagger}$ & $\mathrm{N}$ & $\mathrm{Wt}$ & $\mathrm{N}$ & $\mathrm{Wt}$ & $\mathrm{N}$ & $\mathrm{Wt}$ \\
\hline PHSC1201_E & $4.8^{\mathrm{b} \S}$ & $3934^{b}$ & $1.0^{\mathrm{a}}$ & $812.2^{\mathrm{a}}$ & $4.3 .0^{\mathrm{b}}$ & $1933.0^{b}$ & $9.7^{\mathrm{b}}$ & $5799.2^{\mathrm{b}}$ \\
\hline PHSC1102_E & $0.2^{\mathrm{a}}$ & $1.7^{\mathrm{a}}$ & $0.0^{\mathrm{a}}$ & $0.0^{\mathrm{a}}$ & $0.0^{\mathrm{a}}$ & $0.0^{\mathrm{a}}$ & $0.5^{\mathrm{a}}$ & $67.5^{\mathrm{a}}$ \\
\hline PHSC0933_E & $0.0^{\mathrm{a}}$ & $0.0^{\mathrm{a}}$ & $0.0^{\mathrm{a}}$ & $0.0^{\mathrm{a}}$ & $0.0^{\mathrm{a}}$ & $0.0^{\mathrm{a}}$ & $0.0^{\mathrm{a}}$ & $0.0^{\mathrm{a}}$ \\
\hline B117_E & $17.0^{\mathrm{c}}$ & $6358.5^{c}$ & $21.6^{\mathrm{b}}$ & $4797.0^{\mathrm{b}}$ & $9.8^{\mathrm{c}}$ & $10308.2^{\mathrm{b}}$ & $25.3^{c}$ & $5319.0^{\mathrm{b}}$ \\
\hline PHSC1201_Ut & $0.8^{\mathrm{a}}$ & $644.2^{\mathrm{b}}$ & $0.1^{\mathrm{a}}$ & $40.0^{\mathrm{a}}$ & $1.1^{\mathrm{a}}$ & $606.7^{\mathrm{a}}$ & $7.4^{\mathrm{a}}$ & $2295.8^{a}$ \\
\hline PHSC1102_U & $11.2^{\mathrm{b}}$ & $110.0^{\mathrm{a}}$ & $7.6^{\mathrm{b}}$ & $44.8^{\mathrm{a}}$ & $4.7^{\mathrm{b}}$ & $21.2^{\mathrm{a}}$ & $56.9^{\mathrm{b}}$ & $1265.0^{\mathrm{a}}$ \\
\hline
\end{tabular}

${ }^{\top} \mathrm{N}$, mean number of broomrape shoots per plant; Wt, mean shoot weight (mg).

$\$$ E: Emerged sunflower broomrape structures; U: Underground sunflower broomrape structures.

$\S_{\text {Different lowercase letters within columns indicate significant differences (Tukey test, } P<0.05 \text { ) }}$ 
Table 2. Responses of inbred sunflower lines to Orobanche cumana infection in mini-rhizotrons.

\begin{tabular}{|c|c|c|c|c|c|c|c|c|c|c|c|c|}
\hline \multirow[t]{2}{*}{ Sunflower genotype } & \multicolumn{2}{|c|}{$\begin{array}{l}O . \quad \text { cumana seed } \\
\text { germination }(\%)\end{array}$} & \multicolumn{2}{|c|}{$\begin{array}{l}\text { Germinated seeds that } \\
\text { contacted host roots } \\
(\%)\end{array}$} & \multirow{2}{*}{$\begin{array}{l}\begin{array}{l}\text { Contacted } \\
\text { formed } \\
\text { organs (\%) }\end{array} \\
\mathrm{F}_{\mathrm{GV}} \\
\end{array}$} & \multirow{2}{*}{$\begin{array}{l}\begin{array}{r}\text { radicles that } \\
\text { attachment }\end{array} \\
\mathrm{G}_{\mathrm{TK}} \\
\end{array}$} & \multicolumn{2}{|c|}{$\begin{array}{l}\text { Mean no. tubercles } \\
\text { / plant }\end{array}$} & \multirow{2}{*}{$\begin{array}{l}\text { Tubercles with } \\
(\%) \\
F_{\mathrm{GV}} \\
\end{array}$} & \multirow{2}{*}{$\begin{array}{c}\text { necrosis } \\
\mathrm{G}_{\mathrm{TK}}\end{array}$} & \multicolumn{2}{|c|}{ Tubercle weight (mg) } \\
\hline & $\mathrm{F}_{\mathrm{GV}}$ & $\mathrm{G}_{\mathrm{TK}}$ & $\mathrm{F}_{\mathrm{GV}}$ & $\mathrm{G}_{\mathrm{TK}}$ & & & $\mathrm{F}_{\mathrm{GV}}$ & $\mathrm{G}_{\mathrm{TK}}$ & & & $\mathrm{F}_{\mathrm{GV}}$ & $\mathrm{G}_{\mathrm{TK}}$ \\
\hline PHSC1201 (Or5) & $49.2^{\mathrm{b}^{\dagger}}$ & $57.0^{\mathrm{a}}$ & $13.5^{\mathrm{a}}$ & $14.1^{\mathrm{a}}$ & $56.2^{\mathrm{a}}$ & $52.0^{\mathrm{a}}$ & $33.7^{\mathrm{b}}$ & $46.2^{b}$ & $26.5^{\mathrm{a}}$ & $25.5^{\mathrm{a}}$ & $32.7^{\mathrm{b}}$ & $46.3^{b}$ \\
\hline PHSC1102 (Or & $63.2^{\mathrm{a}}$ & $51.7^{\mathrm{a}}$ & $8.8^{\mathrm{a}}$ & $8.8^{\mathrm{a}}$ & $52.8^{\mathrm{a}}$ & $51.7^{\mathrm{a}}$ & $27.2 .^{b}$ & $40.0^{\mathrm{b}}$ & $21.8^{\mathrm{a}}$ & $19.9^{\mathrm{a}}$ & $0.1^{\mathrm{a}}$ & $0.6^{\mathrm{a}}$ \\
\hline PHSC0933 (Or7) & $43.7^{\mathrm{a}}$ & $51.2^{\mathrm{a}}$ & $7.4^{\mathrm{a}}$ & $8.7^{\mathrm{a}}$ & $47.5^{\mathrm{a}}$ & $51.5^{\mathrm{a}}$ & $0.0^{\mathrm{a}}$ & $0.0^{\mathrm{a}}$ & - & - & - & - \\
\hline B117 & $54.5^{\mathrm{ab}}$ & $55.2^{\mathrm{a}}$ & $11.9^{\mathrm{a}}$ & $11.7^{\mathrm{a}}$ & $56.0^{\mathrm{a}}$ & $52.0^{\mathrm{a}}$ & $33.2^{\mathrm{b}}$ & $44.5^{b}$ & $26.0^{\mathrm{a}}$ & $20.9^{\mathrm{a}}$ & $30.0^{\mathrm{b}}$ & $35.7^{\mathrm{b}}$ \\
\hline
\end{tabular}

Different lowercase letters within columns indicate significant differences (Tukey test, $P<0.05$ ). 